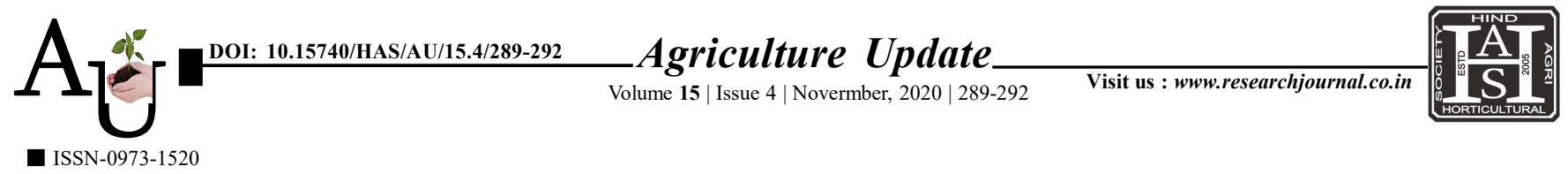

\title{
Research AвтіLі: Constraints faced by the sericulture farmers in adoption of recommended sericulture cultivation practice in Northern Karnataka
}

Article Chronicle:
Received :
12.05.2020;
Revised:
17.09.2020;
Accepted :
05.10.2020

KeY WoRDS : Sericulture farmers, Adoption of recommended, Sericulture cultivation practice

\section{Author for correspondence :}

\section{K.N. Manohar} Department of Agricultural Extension Education, College of Agriculture (UASD), Vijayapur (Karnataka) India

Email: manoharkn77@ gmail.com

See end of the article for authors' affiliations
SUMMARY : The study was conducted in Vijayapur and Bagalkote districts of Northern Karnataka, India in 2019-20, which comes under non-traditional areas ofsericulture. The sample size selected was 120 and it was reported that cent per cent of the farmers reported low price and transportation to the distant markets asthe major problems. More than 90.00 per cent of the farmers faced the difficulties in controlling uji flies and other diseases, high labour charges, high initial establishment cost and lack of information about bio-fertilizers. Keeping these constraints into consideration the suitable policy had been framed by the the government. Added to that the most suited situational extension strategies have been implemented which helped to improve sericulture status.

How to cite this article : Manohar, K.N., Belli, R.B., Gotyal, S.H. and Chavan, S.S. (2020). Constraints faced by the sericulture farmers in adoption of recommended sericulture cultivation practice in Northern Karnataka. Agric. Update, 15(4): 289-292; DOI : 10.15740/HAS/AU/15.4/289-292. Copyright@ 2020: Hind Agri-Horticultural Society. 